\title{
AKSELERASI PEMAHAMAN MATERI SHARAF MELALUI METODE TAMYIZ BERBASIS PERAGAAN PADA MAHASISWA IAIN KENDARI
}

\author{
Wa Muna \\ Fakultas Tarbiyah dan Ilmu Keguruan Institut Agama Islam Negeri Kendari \\ wamuna969@yahoo.co.id
}

\begin{abstract}
This research discusses the application the Tamyiz method based demonstration in learning Arabic as a measure to accelerate the understanding the content ofsharf through tamyiz methods for the students of second semester of Arabic Education Program (PBA) Tarbiyah Faculty and Science Teaching (FTIK) Inistitut Islamic Studies (IAIN) Kendari. This research is the Classroom Action Research (CAR), which is conducted within two cycles and three actions. The first cycle consists of four steps, are: Planning, action or measurement, Observation, Reflections.The results indicated that the application of Tamyiz methods based demonstration to accelerate the understanding content of sharf for the students of the second semester of PBA FTIK IAIN Kendari. From the total 20 students in pre-cycle it obtained that the total score 1257 , and the average score of students is 62.85 , the highest score is 85 and the lowest one is 50 . There are two students who complete the minimum mastery score (KKM) 75. At the first cycle, the total score takes up 1476.88 with the highest score is 89 and the lowest one is 61.5 to obtain the average score 73.844 which represented an increase about 10.827 , and nine people or $45 \%$ obtain the competence standard score. Meanwhile, the second cycle gain the total of score up to 1670 with the average score is 83.5 and the highest score is 100 , and also the lowest one is 70 . In this cycle, there are seven students or $85 \%$ who pass the passing grade.
\end{abstract}

Keywords: Acceleration, Content of Sharaf, Tamyiz Methods.

\begin{abstract}
Abstrak
Penelitian ini membahas tentang penerapan metode tamyiz berbasis peragaan dalam pembelajaran bahasa Arab untuk mengakselerasi pemahaman materi sharaf melalui metode tamyiz pada mahasiswa semester II Program studi Pendidikan Bahasa Arab (PBA) Fakultas Tarbiyah dan Ilmu Keguruan (FTIK) Inistitut Agama Islam Negeri(IAIN) Kendari. Penelitian ini adalah Penelitian Tindakan Kelas (PTK) yang dilakukan melalui dua siklus dan tiga tindakan yang masing-masing siklus terdiri atas empat langkah, yaitu perencanaan, tindakan, observasi, dan refleksi. Hasil penelitian menunjukkan bahwa penerapan metode tamyiz berbasis peragaan dapat mengakselerasi pemahaman materi sharaf pada mahasiswa semester II PBA FTIK
\end{abstract}


IAIN Kendari. Dari jumlah 20 orang mahasiswa pada pra siklus diperoleh jumlah nilai 1257 , rata-rata nilai mahasiswa 62,85 , nilai tertinggi 85 dan nilai terendah 50 , dan terdapat 2 orang mahasiswa yang tuntas memenuhi ketuntasan minimal (KKM) 75. Pada siklus I diperoleh jumlah nilai 1476,88 nilai tertinggi 89 dan nilai terendah 61,5 sehingga diperoleh nilai rata-rata 73,844 yang berarti mengalami peningkatan sebesar 10,827, dan terdapat.9 orang atau $45 \%$ yang memenuhi ketuntasan belajar. Dan pada siklus II jumlah nilai 1670, nilai rata-rata 83,5 nilai tertinggi 100 dan nilai terendah 70 dan terdapat 17 orang atau $85 \%$. Mahasiswa yang tuntas belajar memenuhi KKM.

\section{Kata Kunci: Akselerasi, Materi Sharaf, Metode Tamyiz.}

\section{A. PENDAHULUAN}

Akselerasi dalam Kamus Besar Bahasa Indonesia didefinisikan sebagai proses mempercepat, peningkatan percepatan, laju perubahan kecepatan. Akselerasi dalam dunia pendidikan dapat diartikan sebagai peningkatan, pertambahan terhadap pemahaman atau penguasaan materi pelajaran tertentu. Demikian pula dalam pembelajaran bahasa Arab, membutuhkan suatu upaya tertentu untuk dapat mengakselerasi pemahaman terhadap materi bahasa Arab tersebut. Salah satu langkah untuk menumbuhkan minat dan memotivasi para siswa untuk belajar bahasa Arab adalah dengan cara menciptakan/menerapkan metode yang tepat dalam pembelajaran, sehingga siswa lebih bergairah dan tidak merasa bosan selama belajar bahasa Arab.

Hasil observasi tahun 2013- 2015 menunjukan bahwa pembelajaran bahasa Arab di IAIN Kendari menggunakan metode Intiqaaiyyah atau metode eklektik dalam pembelajaran bahasa Arab, termasuk pembelajaran materi nahwu sharaf, Qawaid atau Tata bahasa Arab dan hanya dosen tertentu saja yang menggunakan metode tamyiz. Metode Intiqaaiyyah atau metode eklektik ini adalah suatu bentuk penggabungan dari beberapa metode yang sehaluan atau tujuannya sama. Misalnya Metode muthalaah (membaca) digabung dengan metode qawaid (nahwu sharaf) dan tarjamah (terjemahan). Metode Intiqaiyyah ini dianggap sebagai salah satu solusi untuk mengatasi kejenuhan dalam proses pembelajaran bahasa Arab di kelas.

Metode Intiqaiyyah ini dapat menjadi metode yang ideal manakala dosen/guru menguasai beberapa metode pembelajaran bahasa Arab, sehingga dapat meyesuaikannya dengan kebutuhan program pembelajarannya yang kemudian menerapkannya secara proporsional. Sebaliknya guru/dosen yang 
tidak menguasai berbagai metode pembelajaran bahasa Arab, maka metode ini akan menjadi metode seadanya sesuai dengan selera dosennya. Apabila pemilihan metode pembelajaran sesuai selera dosen, maka yang terjadi adalah ketidakmenentuan hasil pembelajaran yang hendak dicapai. Oleh sebab itu, penggunaan metode ini membutuhkan penguasaan beberapa metode yang sehaluan dan keterampilan khusus dalam penerapannya pada saat penyajian materi tersebut.

Salah satu cabang materi pembelajaran bahasa Arab adalah Sharaf. Materi ini termasuk materi yang sulit dipahami peserta didik. Metode pembelajaran ilmu ini cukup banyak dipraktekkan oleh para guru/dosen, akan tetapi peserta didik tetap saja menghadapi kesulitan dalam mempelajarinya. Oleh karena itu, perlu digunakan suatu metode pembelajaran yang diprioritaskan lebih dahulu untuk diajarkan pada para peserta didik, sehingga dapat mempermudah mereka dalam mempelajari materi Sharaf.

Di IAIN Kendari, kendala yang dihadapi oleh para mahasiswa selama ini adalah sulitnya memformulasikan teori Sharaf dengan cara pembelajaran yang mudah, karena itu Sharaf terlanjur dipresepsikan sebagai pelajaran yang sulit. Kendala tersebut disebabkan oleh (1) mahasiswa harus belajar membaca kitab sharaf, (2) mahasiswa harus belajar mentashrif, (2) mahasiswa harus belajar memahami wazan tashrif, (3) mahasiswa harus belajar mengaplikasikan wazan tersebut pada kitab bahasa Arab yang lain, bahkan pada kitab tertentu harus menghafal wazan tashrif lughawiy dan wazan tashrif ishtilahi. Oleh karena itu, perlu ada solusi untuk mengatasi hal tersebut. Hal ini tentu berkaitan dengan metode atau cara menyampaikan materi tersebut kepada mahasiswa, sehingga mereka dapat dengan mudah memahami atau menguasai materi tersebut. Salah satu cara untuk mempermudah pembelajaran sharaf adalah menggunakan metode tamyiz/mumtaz.

Observasi awal yang dilakukan oleh penulis pada kelas mahasiswa bidik misi IAIN Kendari pada Semeter Ganjil Tahun Ajaran 2015, dalam pembelajaran bahasa Arab menggunakan metode tamyiz, mahasiswa lebih cepat menguasai materi pembelajaran daripada kelas yang menggunakan metode lain, seperti metode qawaid, tarjamah dan yang lainnya. ${ }^{1}$

Tulisan ini akan membahas bagaimana efektivitas penerapan metode tamyiz berbasis peragaan dapat mengakselerasi pemahaman materi sharaf

\footnotetext{
${ }^{1}$ Observaasi, Kendari Tanggal 24-25 Oktober 2015 dan 28-29 NoVember 2015
} 
pada mahasiswa semester II Progranm Studi Bahasa Arab Fakultas Tarbiyah dan Ilmu Keguruan IAIN Kendari.

\section{B. PRINSIP DAN TAHAP BELAJAR-MENGAJAR METODE TAMYIZ/MUMTAZ DALAM MATERI SHARAF}

Metode tamyiz disebut juga metode Mumtaz yang merupakan temuan seorang ustadz bernama Abaza. Metode ini lahir sebagai usaha dan kreatifitas untuk menyederhanakan materi dan mengembangkan metode pembelajaran, agar materi tersebut dirasakan mudah dan menyenangkan. ${ }^{2}$ Kelahiran metode ini dilatarbelakangi oleh fakta dalam pembelajaran bahasa Arab, pengalaman, dan pengamatan, hasil renungan penulisanya. Penulis buku ini lalu memutuskan menyusun Mumtaz Pure Nahwu dan Akademis. ${ }^{3}$ Metode ini diperuntukan untuk materi nahwu sharaf/materi qawaid (tata bahasa) dengan sasaran komunitas akademik. Bila dibandingkan dengan metode-metode lain, metode ini memiliki spesifikasi khusus dalam penyajian materi nahwu sharaf diantaranya adalah 1) bahasa pengantarnya sederhana (dekat dengan peserta), 2) pembelajaran dilakukan dengan cara bernyanyi (menyenangkan) sehingga tidak membosankan bagi peserta pembelajaran, 3) mengaktifkan seluruh peserta sehingga hasilnya lebih merata, 4) pengulangan materi untuk memastikan penguasaan materi sejak di dalam kelas, 5) pola latihan tidak membebani namun efektif, 6) sistem evaluasi yang terukur, 7) metode penyajian mudah diduplikasi ${ }^{4}$. Metode ini dikatakan mudah diduplikasi karena dilakukan dengan cara belajar sambil bernyanyi. Belajar sambil bernyanyi ini oleh Abaza MM diberi nama metode tamyiz.

Belajar bahasa Arab berarti belajar bahasanya orang Arab atau bangsa Arab. Bahasa Arab masuk dalam kategori bahasa asing bagi orang di luar Arab. Karena ia adalah bahasa asing, maka dalam proses pembelajarannya memiliki proses yang kompleks dengan berbagai fenomena yang pelik, sehingga tidak mengherankan kalau hal ini bisa mempunyai arti yag berbedabeda bagi setiap orang". ${ }^{5}$ Oleh karena itu, bahasa Arab seyogyanya diberi

2 Alimin dan Saifuddin Zuhri, Metode مثتاز Mumtaz cepat \& Mudah Pintar Membaca Kitab Kuning, (Jakarta: Orbit Publishing, 2014), h. Iii - iv.

3 Alimin dan Saifuddin Zuhri, Materi Workshop Pengembangan Metodologi Tamyiz, STAIN Kendari, 17-18 Mei 2014.

${ }^{4}$ Ibid., Materi Workshop.

5 Rosyidi, Abdul Wahab, Media Pembelajaran Bahasa Arab, (Malang: UINMalang Press, 2009), h. 17 
perlakuan khusus dalam proses pembelajarannya agar mudah di pahami oleh semua kalangan, tidak terbatas pada kalangan pelajar dan mahasiswa saja, termasuk juga dalam pemilihan metodenya. Berikut ini akan dijelaskan prinsip belajar dan mengajar metode tamyiz/mumtaz.

\section{B. 1 Prinsip Belajar Tamyiz/Mumtaz}

Prinsip belajar adalah konsep-konsep ataupun asas (kaidah dasar) yang harus diterapkan di dalam proses belajar mengajar. Hal ini mengandung maksud bahwa pendidik akan dapat melaksanakan tugasnya dengan baik, apabila dapat menerapkan cara mengajar sesuai dengan prinsip-prinsip belajar. ${ }^{6}$ Dengan demikian, prinsip-prinsip belajar adalah landasan berpikir, landasan berpijak dan sumber motivasi, dengan harapan tujuan pembelajaran tercapai dan tumbuhnya proses belajar antardidik dan pendidik yang dinamis dan terarah. ${ }^{7}$

Dalam penerapan metode tamyiz, prinsip cara belajarnya ada dua yakni: laduni dan sentot. Laduni (ilate kudu muni) artinya peserta didik belajar dengan teknik mengeraskan suaranya, sebagai salah satu cara untuk mengoptimalkan penggunaan potensi otak kiri dan otak kanan secara seimbang. Ditambah pula dengan teknik pengulangan yang integratif, sebagai salah satu cara mengoptimalkan potensi otak bawah sadar. Sedangkan Sentot (santri TOT) adalah model dimana ustadz yang mengajar/menjelaskan kepada peserta didik/santri. ${ }^{8}$

Perbatasan antara otak sadar dan otak bawah sadar terdapat RAS (rectricular activating system) (Qolbun?). RAS Berfungsi untuk menyaring informasi mana yang harus disimpan atau dibuang. ${ }^{9}$ Pembelajaran dengan menggunakan metode tamyiz melakukan teori dan praktek, dalam hal ini teori dilakukan secara bertahap. Sedangkan praktek dilakukan segera setelah teori diberikan. Selain itu teori diberikan $12 \%$ dan $88 \%$ praktek. ${ }^{10}$ Lebih jelasnya dapat dilihat pada table berikutz:

${ }^{6}$ Riyanto, Yatim, Paradigma Baru Pembelajaran, (Jakarta: Kencana 2009), h. 62.

${ }^{7}$ Ibid., h. 62

${ }^{8}$ Ibid., h. 8

9 Abaza. Anak Kecil Saja Bisa Yang Pernah Kecil Pasti Bisa Pintar Tarjamah Qur'an dan Kitab Kuning, Cet ke- 5, (Indramayu: Tamyiz Publishing, 20130, h. 10.

${ }^{10}$ Ibid., h. 11. 
Tabel 1

Pembagian kerja Otak Kiri dalam Belajar

\begin{tabular}{|c|c|c|c|}
\hline & Visual & Auditorial & Kinestetik \\
\hline Otak aktif & $\begin{array}{l}\text { (otak kiri) wajah } \\
\text { serius, tegang }\end{array}$ & $\begin{array}{l}\text { (otak kanan) wajah } \\
\text { senyum, nyaman }\end{array}$ & $\begin{array}{l}\text { (otak bawah sadar) } \\
\text { mengulang secara } \\
\text { integrative ingatan. } \\
\text { Otak kiri dan otak } \\
\text { kanan sebanyak } 27 \\
\text { kali. }\end{array}$ \\
\hline Kelebihan & $\begin{array}{l}\text { Cepat memahami } \\
\text { informasi }\end{array}$ & $\begin{array}{l}\text { Ingat baik dengan } \\
\text { sampai mati }\end{array}$ & $\begin{array}{l}\text { Ingatannya } \\
\text { menjadi prilaku } \\
\text { image) }\end{array}$ \\
\hline Kelemahan & $\begin{array}{l}\text { Ingatan dengan baik } \\
\text { selama } 2 \text { jam \&lupa } \\
\text { pada hari ke } 27\end{array}$ & $\begin{array}{l}\text { Telmi /lola } \\
\text { membutuhkan } \\
\text { jembatan keledai }\end{array}$ & $\begin{array}{lr}\text { Tidak } & \text { mampu } \\
\text { membedahkan } & \text { benar } \\
\text { dan salah } & \\
\end{array}$ \\
\hline $\begin{array}{l}\text { Cara } \\
\text { belajar }\end{array}$ & $\begin{array}{l}\text { Belajar dengan cara } \\
\text { melihat }\end{array}$ & $\begin{array}{l}\text { Belajar dengan cara } \\
\text { mendengar melalui } \\
\text { informasi }\end{array}$ & $\begin{array}{l}\text { Belajar dengan cara } \\
\text { merasakan melalui } \\
\text { bahasa tubuh, resonansi } \\
\text { dan pengulangan. }\end{array}$ \\
\hline
\end{tabular}

Dua prinsip yang digunakan oleh cara belajar metode tamyiz inilah yang memudahkan santri/siswa/mahasiswa dalam memahami dan menguasai pelajaran yang telah dipelajari karena dilakukan dengan cara yang rileks dan menyenangkan, yakni bernyanyi. Berbicara tentang bernyanyi hampir seluruh manusia di muka bumi ini tidak ada yang tidak bisa bernyanyi. Bahkan lagu yang dinyanyikan sejak kecil sampai tua pun masih tetap di ingat. Dengan bernyanyi akan meningkatkan emosi positif, meningkatkan kekuatan otak, keberhasilan, dan kehormatan diri ${ }^{11}$, sebagaimana yang dijelaskan dalam diagram berikut:

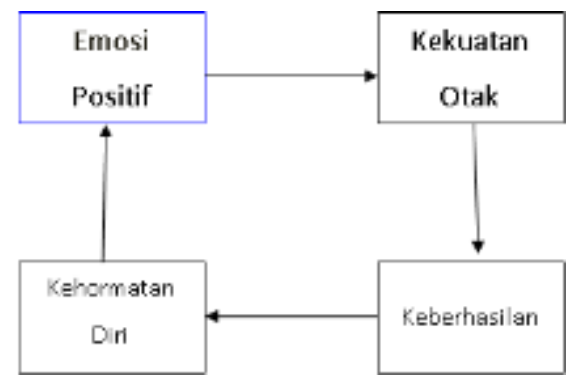

${ }^{11}$ DePorter, Bobby \& Mike Hernacki, Quantum Learning Membiasakan Belajar Nyaman Dan Menyenangkan, (Bandung: Kaifa, 2001), h.41. 
Diagram tersebut mengisyaratkan bahwa emosi positif yang dimiliki seseorang akan menjadikan orang tersebut berpikir positif untuk berkreasi yang pada akhirnya akan mendorong seseorang untuk membuat suatu keputusan dengan penuh keyakinan serta akan melahirkan kekuatan pribadi. Ini lahir dari meningkatnya kekuatan otak. Apabila kekuatan otak ini berlangsung secara maksimal, maka akan melahirkan suatu keberhasilan dan apabila keberhasilan itu diraih atau terwujud, akan berdampak pula pada kehormatan diri seseorang.

\section{B.2 Prinsip Mengajar Tamyiz/Mumtaz}

Prinsip Mengajar Tamyiz ada dua, yakni prinsip umum dan prinsip khusus. Dua prinsip tersebut akan diuraikan sebagai berikut:

a) Prinsip Umum. Prinsip umum mengajar tamyiz yakni cara mengajar lebih penting dari materi (yang diajarkan) الطريقة اهم من المدة yang paling penting adalah cara mengajarkannya (Thariqah) yang harus bisa dipelajari oleh anak kecil karena begitu mudah thariqahnya. ${ }^{12}$

b) Prinsip Khusus yakni mengajar dengan bahasa hati dan mengajar dengan mematuhi tahapan ${ }^{13}$. Karena mengajar dengan bahasa hati, maka prinsip mengajarnya menggunakan "prinsip mengajar cara fun and active teaching dan jauh dari perilaku kasar, galak dan menakutkan bagi peserta didik"14

Prinsip belajar mengajar metode tamyiz adalah mudah, dalam arti proses pembelajarannya harus dirasakan mudah oleh para peserta didik. Kesan akhir peserta didik adalah "kalau hanya begitu caranya, saya juga bisa mengajarkan tamyiz. ${ }^{15}$

\section{B.3 Materi Sharaf}

\footnotetext{
${ }^{12}$ Abaza, loc.cit. h. 8

${ }^{13}$ Ibid.

${ }^{14}$ Ibid.h. 12

${ }^{15}$ Ibid, h. 8
} 
Ibnu Thaha berpendapat bahwa Sharaf atau dibaca Shorof adalah salah satu nama cabang Ilmu dalam pelajaran Bahasa Arab yang khusus membahas tentang perubahan bentuk kata (Bahasa Arab: kalimat). Perubahan bentuk kata ini dalam prakteknya disebut Tashrif. Oleh karena itu dinamakan Ilmu Sharaf (perubahan; berubah), karena Ilmu ini khusus mengenai pembahasan Tashrif (pengubahan; mengubah). ${ }^{16}$

Materi Sharaf dapat diterapkan dengan menggunakan metode tamyiz. Karena metode pembelajaranya mudah, praktis, dan menyenangkan untuk dapat menterjemahkan Alquran dan kitab Kuning. Metode tamyiz ini dapat dipelajari sedini mungkin. Metode tamyiz ini akan memudahkan peserta didik untuk dapat membaca sekaligus menguraikan kosa kata atau struktur kata yang terdapat dalam al-Qur'an ataupun kitab-kitab berbahasa Arab. Dengan demikian, paradigma yang harus dikembangakan adalah mempelajari bahasa Arab dengan metode yang mudah bukan sebaliknya. Mempelajari alQur'an dengan metode al-Qur'an bukan dengan metode bahasa Arab. Karena belum tentu orang yang bisa berbahasa Arab mampu memahami Al-Quran, tetapi ajaibnya orang yang bisa memahami al-Qur'an bisa dengan mudah mempelajari bahasa Arab". ${ }^{17}$

Metode tamyiz dilakukan dalam bentuk nyanyian yakni menyanyikan rumus-rumus atau wazan-wazan dari materi pembelajaran tersebut. Demikian pula dengan pembelajaran Sharaf. Materi-materinya apabila diajarkan dengan metode yang dapat menggugah motivasi untuk belajar, maka materinya akan menjadi lebih menyenangkan. Metode tamyiz dapat memberikan nuansa baru bagi peserta didik dalam belajar bahasa Arab, khususnya materi sharaf apabila ditunjang oleh pengajar yang dapat menerapkan materi tersebut dengan menggunakan metode tamyiz.

\section{AKSELERASI PEMAHAMAN MATERI SHARAF MELALUI METODE TAMYIZ BERBASIS PERAGAAN}

\section{Kegiatan Pra Siklus}

Sebelum kegiatan siklus dimulai terlebih dahulu dilakukan tes awal yang bertujuan untuk mengetahui kemampuan dasar mahasiswa semester II Program studi Pendidikan Bahasa Arab ( PBA ) Fakultas Tarbiyah dan Ilmu Keguruan (FATIK) Institut Agama Islam Negeri (IAIN) Kendari tentang

\footnotetext{
${ }^{16} \mathrm{Ibnu}$ Thaha, https://nahwusharaf.wordpress.com/2010/06/24/definisi-sharaf/

${ }^{17}$ http://unissula.ac.id/tamyis-metode-terjemah-quran-praktis/23-12-2015
} 
penguasaan materi sharaf yang telah mereka pelajari sebelumnya dengan metode Qiraah, metode tahfizh, dan metode Intiqaiyyah/eklektik.

\section{Tabel 2}

\section{Nilai Ketuntasan Klasikal Pra siklus}

\begin{tabular}{|c|c|c|c|c|c|c|}
\hline & Interval & $\begin{array}{l}\text { Kategor } \\
\text { i }\end{array}$ & Frekwensi & $\begin{array}{l}\text { Bobot } \\
\text { Skor }\end{array}$ & $\%$ & $\begin{array}{l}\text { Skor rata- } \\
\text { rata }\end{array}$ \\
\hline 1. & $81-100$ & $\begin{array}{c}\text { Sangat } \\
\text { Baik }\end{array}$ & 1 & 83 & 5 & 83 \\
\hline 2. & $61-80$ & Baik & 10 & 632 & $\begin{array}{l}5 \\
0\end{array}$ & 63,2 \\
\hline 3. & $41-60$ & $\begin{array}{c}\text { Cukup } \\
\text { Baik }\end{array}$ & 9 & 489 & $\begin{array}{l}4 \\
5\end{array}$ & 54,33 \\
\hline 4. & $21-40$ & Kurang & - & & & \\
\hline 5. & $\leq 20$ & $\begin{array}{c}\text { Kurang } \\
\text { Sekali }\end{array}$ & - & & & \\
\hline \multicolumn{3}{|c|}{ Jumlah } & & & $\begin{array}{l}1 \\
0 \\
0\end{array}$ & \\
\hline
\end{tabular}

Dari hasil analisis data ketuntasan belajar dapat diketahui bahwa mahasiswa yang tuntas belajar pada pra siklus ini sebanyak $10 \%$ dan yang tidak tuntas sebanyak $90 \%$.

\section{Siklus I}

Dalam siklus ini, mahasiswa telah siap untuk menerima materi pelajaran sesuai dengan skenario pembelajaran yang telah dirancang. Adapun hal-hal yang diobservasi dalam proses pembelajaran adalah sikap siswa selama mengikuti proses pembelajaran, yakni keaktifan siswa selama belajar kelompok, sikap dan cara dosen dalam menyampaikan materi pelajaran yang disesuaikan dengan metode tamyiz berbasis peragaan.

Setelah melakukan siklus I sebanyak tiga kali pertemuan, maka pertemuan keempat dilakukan evaluasi untuk mengetahui perkembangan peserta didik dalam memahami materi sharaf dengan menggunakan metode tamyiz berbasis peragaan. Berikut ini akan diuraikan hasil perolehan nilai saat evaluasi siklus I.

\section{Tabel 3}

\section{Nilai Ketuntasan Klasikal siklus I}




\begin{tabular}{|c|c|c|c|c|c|c|}
\hline $\begin{array}{l}\mathrm{N} \\
\mathrm{o} .\end{array}$ & Interval & Kategori & Frekwensi & $\begin{array}{r}\text { Bobot } \\
\text { Skor }\end{array}$ & $\%$ & $\begin{array}{r}\text { Skor } \\
\text { rata-rata }\end{array}$ \\
\hline 1. & $81-100$ & $\begin{array}{c}\text { Sangat } \\
\text { Baik }\end{array}$ & 2 & 177.33 & 10 & 88,665 \\
\hline 2. & $61-80$ & Baik & 18 & 1296.21 & 90 & 72.0116 \\
\hline 3. & $41-60$ & $\begin{array}{l}\text { Cukup } \\
\text { Baik }\end{array}$ & - & - & - & - \\
\hline 4. & $21-40$ & Kurang & - & - & - & - \\
\hline 5. & $\leq 20$ & $\begin{array}{l}\text { Kurang } \\
\text { Sekali }\end{array}$ & - & - & - & - \\
\hline & Jumlah & & & & $\begin{array}{r}10 \\
0\end{array}$ & \\
\hline
\end{tabular}

Sumber Data: Hasil Pengolahan Data Penelitian 2016

Dari tabel tersebut diperoleh gambaran bahwa 2 orang atau $10 \%$ berkategori sangat baik dan $90 \%$ berkategori baik. Apabila dihitung berdasarkan prosaentase ketuntasan belajar, maka akan diperoleh hasil sebagai berikut:

$$
\% \text { ketuntasan }=\frac{\sum X}{N} \times 100 \%=\frac{9}{20} \times 100 \%=45 \% .
$$

Dengan demikian ketuntasan belajar mahasiswa berdasarkan persentase ketuntasan bealajarnya adalah $45 \%$, artinya meningkat sekitar $25 \%$ dari pra siklus atau tes awal

\section{Siklus II}

Berdasarkan hasil observasi, evaluasi dan refleksi pada tindakan siklus I, peneliti bersama-sama dengan dosen merencanakan tindakan berikutnya yakni siklus II. Proses pembelajaran melalui metode tamyiz berbasis peragaan kembali dilakukan sebagai kelanjutan pelaksanaan penelitian ini dengan memperhatikan hasil refleksi pada tindakan siklus I. Proses pembelajaran pada tindakan siklus II ini telah mengalami peningkatan dari siklus I. Berdasarkan hasil observasi, dosen dan mahasiswa diketahui bahwa mereka bersama-sama melaksanakan proses pembelajaran dengan menggunakan metode tmyiz berbasis peragaan.

Setelah tindakan kegiatan siklus II selesai, kegiatan berikutnya adalah melakukan tes tindakan siklus II untuk melihat tingkat penguasaan mahasiswa terhadap materi. 
Tabel 4

Nilai Ketuntasan Klasikal siklus II

\begin{tabular}{|c|c|c|c|c|c|c|}
\hline No. & Interval & Kategori & Frekwensi & $\begin{array}{l}\text { Bobot } \\
\text { Skor }\end{array}$ & $\%$ & $\begin{array}{l}\text { Skor } \\
\text { rata- } \\
\text { rata }\end{array}$ \\
\hline 1. & $81-100$ & $\begin{array}{c}\text { Sangat } \\
\text { Baik }\end{array}$ & 8 & 666 & 40 & 83,25 \\
\hline 2. & $61-80$ & Baik & 12 & 918 & 60 & 76,5 \\
\hline 3. & $41-60$ & $\begin{array}{l}\text { Cukup } \\
\text { Baik }\end{array}$ & - & - & - & - \\
\hline 4. & $21-40$ & Kurang & - & - & - & - \\
\hline 5. & $\leq 20$ & $\begin{array}{c}\text { Kurang } \\
\text { Sekali }\end{array}$ & - & - & - & - \\
\hline \multicolumn{3}{|c|}{ Jumlah } & & & 100 & \\
\hline
\end{tabular}

Sumber Data: Hasil Pengolahan Data Penelitian 2016

Dari tabel tersebut diperoleh gambaran bahwa 8 orang atau $40 \%$ berkategori sangat baik dan 12 orang atau $60 \%$ berkategori baik. Apabila dihitung berdasarkan persentase ketuntasan belajarnya, maka akan diperoleh hasil sebagai berikut:

$$
\% \text { ketuntasan }=\frac{\Sigma X}{N} \times 100 \%=\frac{17}{20} \times 100 \%=85 \% .
$$

Dengan demikian ketuntasan belajar mahasiswa apabila dipersentasikan adalah $85 \%$, atau meningkat sekitar $40 \%$ dari siklus II dan yang tidak tuntas terdapat 3 orang.

Dengan demikian, maka terdapat peningkatan prestasi belajar mahasiswa dari siklus I ke siklus II. Pada pelaksanaan tindakan siklus I hasil belajar mahasiswa adalah $45 \%$ yang memperoleh nilai $\geq 75$ atau berjumlah 17 orang dari 20 mahasiswa, sehingga penelitian ini dilanjutkan pada siklus II sebab belum mencapai indikator kinerja yang telah ditetapkan (80\%). Salah satu penyebab sehingga hasil penelitian belum mencapai indikator kinerja yang telah ditetapkan adalah mahasiswa belum sepenuhnya memahami penggunaan metode tamyiz berbasis peragaan.

Pada pelaksanaan tindakan siklus II, diperoleh hasil belajar mshssiswa sebesar $85 \%$ yang memperoleh nilai $\geq 75$. Dari siklus I (45\%) ke siklus II (85\%) meningkat sebesar $40 \%$. Kenaikan prestasi belajar siswa dari siklus I ke siklus II disebabkan karena pelaksanaan skenario pembelajaran semakin 
sempurna dan mahasiswa semakin memahami penggunaan metode tamyiz berbasis peragaan. Berdasarkan hasil tes pada tindakan siklus II, maka penelitian ini tidak dilanjutkan pada siklus berikutnya karena indikator keberhasilan penelitian ini telah tercapai. Dengan demikian sutu upaya untuk meningkatkan hasil belajar mahasiswa dalam materi Sharf I ( wazan tashrif : fiil madhi, Fi'il mudhari, dan fi'il Amar) melalui metode tamyiz berbasisperagaan telah terlaksana dengan baik.

Pelaksanaan pembelajaran dengan menggunakan metode tamyiz bebasis peragaan ini pada proses pembelajaran yang dilakukan dalam 2 siklus ini diperoleh hasil dari aktivitas mahasiswa dan dosen sebagai berikut:

\section{a. Aktifitas Mahasiswa}

Aktifitas belajar mahasiswa lebih aktif dan memberikan respon positif dan mereka cukup antusias dalam mengikuti proses pembelajaran sebagaimana tertera pada tabel berikut:

\section{Tabel 5}

\section{Hasil Observasi Aktifitas MahasiswaPada Siklus I Dan II}

\begin{tabular}{|c|c|c|c|}
\hline \multirow[t]{2}{*}{ No } & \multirow[t]{2}{*}{ Hal yang Diamati } & \multicolumn{2}{|c|}{ Nilai } \\
\hline & & $\begin{array}{c}\text { Siklus } \\
\text { I }\end{array}$ & $\begin{array}{l}\text { Siklus } \\
\text { II }\end{array}$ \\
\hline 1 & $\begin{array}{l}\text { Keaktifan Siswa: } \\
\text { Mahasiswa aktif mencatat materi pelajaran } \\
\text { b. Mahasiswaktif bertanya } \\
\text { c. Mahasiswa aktif mengajukan ide }\end{array}$ & 3 & 4 \\
\hline 2 & $\begin{array}{l}\text { Perhatian Siswa: } \\
\text { a. Diam, tenang } \\
\text { b. Terfokus pada materi } \\
\text { c. Antusias }\end{array}$ & 4 & 4 \\
\hline 3 & $\begin{array}{l}\text { Kedisiplinan: } \\
\text { a. Kehadiran/absensi } \\
\text { b. Datang tepat waktu } \\
\text { c. Pulang tepat waktu }\end{array}$ & 3 & 4 \\
\hline 4 & 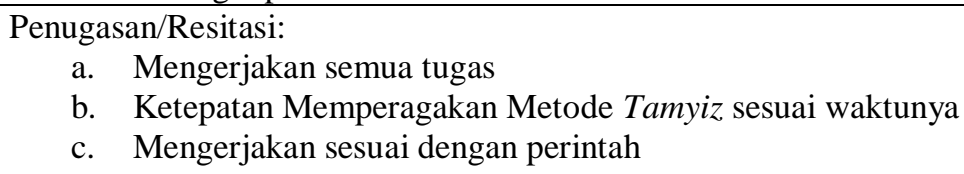 & 4 & 4 \\
\hline & Rata-Rata & 3,5 & 4 \\
\hline & Kategori & $\begin{array}{l}\text { Sangat } \\
\text { Baik }\end{array}$ & $\begin{array}{l}\text { Sangat } \\
\text { Baik }\end{array}$ \\
\hline
\end{tabular}


Keterangan;

4: Sangat Baik

3: Baik

2: Tidak Baik

1: Sangat Tidak Baik

Berdasarkan hasil observasi aktivitas mahasiswapada siklus I dan II tersebut ditemukan bahwa terjadi peningkatan aktivitas belajar mahasiswa dari sebelumnya, dimana pada siklus I nilai rata-rata 3,5 sedangkan pada siklus II terjadi peningkatan sebesar 0,5, sehingga menjadi 4 dengan kategori sangat baik. Dengan adanya peningkatan jumlah skor aktivitas mahasiswa tersebut menggambarkan bahwa penggunaan metode tamyiz berbasis peragaan ini bagi peserta didik dapat mengekspresikan apa yang ada dalam pikirannya.

b. Aktifitas Dosen

Aktivitas dosen dalam pembelajaran sanrgat mempengaruhi sukses tidaknya atau berhasil tidaknya suatu proses pembelajaran dilakukan oleh seorang dosen. Aktivitas pembelajaran yang dilakukan dosen dengan menggunakan metode tamyiz berbasis peragaan ini dapat meningkatkan kinerja dosen dalam menciptakan pembelajaran yang lebih kreatif dan inovatif. Aktifitas kegiatan dosen mendapat skor rata-rata 3,16 atau dengan kategori baik dan pada siklus II skor. Kegiatan dosen mengalami peningkatan sebesar 0,84 menjadi 4. Hal ini menunjukkan bahwa aktivitas dosen dalam mengelola proses pembelajaran telah berhasil. Secara terperinci aktivitas kegiatan dosen dengan menggunakan metode tamyiz ini dapat diuraikan pada tabel berikut: 
Tabel 6

Hasil Observasi Aktifitas Dosen Pada Siklus I Dan II

\begin{tabular}{|c|c|c|c|}
\hline No & Hal yang Diamati & & \\
\hline & Dosen & $\begin{array}{c}\text { Siklus } \\
\text { I }\end{array}$ & $\begin{array}{l}\text { Siklus } \\
\text { II }\end{array}$ \\
\hline 1 & $\begin{array}{l}\text { Penguasaan Materi: } \\
\text { a. Kelancaran menjelaskan materi } \\
\text { b. Kemampuan menjawab pertanyaan } \\
\text { c. Keragaman pemberian contoh } \\
\end{array}$ & 3 & 4 \\
\hline 2 & $\begin{array}{l}\text { Sistematika penyajian: } \\
\text { a. Ketuntasan uraian materi } \\
\text { b. Uraian materi mengarah pada tujuan } \\
\text { c. Urutan materi sesuai dengan perurutannya }\end{array}$ & 3 & 4 \\
\hline 3 & $\begin{array}{l}\text { Penerapan Metode: } \\
\text { a. Ketepatan pemilihan metode sesuai materi } \\
\text { b. Keseuaian urutan sintaks dengan metode yang } \\
\text { digunakan } \\
\text { c.Mudah diikuti siswa }\end{array}$ & 3 & 4 \\
\hline 4 & $\begin{array}{l}\text { Penggunaan Media: } \\
\text { a. Ketepatan pemilihan media dengan materi } \\
\text { b. Ketrampilan menggunakan media } \\
\text { c. } \text { Media memperjelas terhadap materi }\end{array}$ & 4 & 4 \\
\hline 5 & $\begin{array}{ll}\text { Performance: } \\
\text { a. } \\
\text { bejelasan suara yang diucapkan } \\
\text { c. Kekomunikatifan dosen dengan mahasiswa } \\
\text { Keluwesan sikap dosen dengan mahasiswa }\end{array}$ & 3 & 4 \\
\hline 6 & $\begin{aligned} & \text { Pemberian Motivasi: } \\
& \text { a. } \text { Keantusiasan dosen dalam mengajar } \\
& \text { b. } \text { Kepedulian dosen terhadap mahasiswa } \\
& \text { c. } \text { Ketepatan pemberian reward dan punishman }\end{aligned}$ & 3 & 4 \\
\hline & Rata-Rata & 3.16 & 4 \\
\hline & Kategori & Baik & $\begin{array}{l}\text { Sangat } \\
\text { Baik }\end{array}$ \\
\hline
\end{tabular}

Keterangan;

4: Sangat Baik

3: Baik

2: Tidak Baik

1: Sangat Tidak Baik

D. PENUTUP 
Penerapan metode tamyiz berbasis peragaan dapat mengakselerasi pemahaman materi sharaf pada mahasiswa semester II PBA FTIK IAIN Kendari. Pada tindakan siklus I dalam proses pembelajaran sharaf I (wazan tashrif: fiil madhi, fi'il mudhari, dan fi 'il amar) belum berlangsung sempurna. Hal ini disebabkan karena mahasiswa belum sepenuhnya memahami penerapan atau cara menggunakan metode tamyiz berbasis peragaan dan dosen kurang memotivasi mahasiswa. Selain itu, dosen juga belum maksimal dalam membimbing mahasiswa yang bermasalah dalam menyesuaikan lirik lagu yang dimiliki dengan materi wazan fi'il madhi, fi'il mudhri, dan fiil amar. Nilai ketuntasan belajar mahasiswa pada siklus I ini baru mencapai $45 \%$ atau terdapat 9 orang yang tuntas dan $55 \%$ atau sebanyak 11 orang mahasiswa yang belum tuntas.

Pada tindakan siklus II, proses pembelajaran berlangsung sesuai rencana. Hal ini disebabkan karena mahasiswa telah memahami cara menggunakan metode tamyiz berbasis peragaan dan dapat mengaplikasikan lirik lagu yang dikuasai dalam materi wazan tashrif yang ditugaskan kepadanya. Disamping itu, dosen dalam mengajar telah berjalan sesuai dengan rencana. Mahasiswa mengalami peningakatan prestasi belajarnya dari Siklus I ke Siklus II dengan ketuntasan belajar sebesar $85 \%$ atau sebanyak 17 orang dari 20 mahasiswa yang sudah tuntas dan $15 \%$ atau 3 orang mahasiswa yang belum tuntas. Metode tamyiz berbasis peragaan dapat diterapkan untuk mengakselerasi pemahaman materi sharaf pada mahasiswa semester II Progran Studi Bahasa Arab, Fakultas tarbiyah dan Ilmu Keguruan IAIN Kendari.

\section{DAFTAR PUSTAKA}

\section{Buku}

Abaza. Tamyiz; Anak Kecil Saja Bisa Yang Pernah Kecil Pasti Bisa Pintar Tarjamah Qur'an dan Kitab Kuning. Cet. Ke-5. Indramayu: Tamyiz Publishing, 2013.

Alimin dan Saifuddin Zuhri. Metode منتاز Mumtaz cepat \& Mudah Pintar Membaca Kitab Kuning. Jakarta: Orbit Publishing, 2014. , Materi Workshop pengembangan Metodologi Tamyiz. STAIN Kendari, 17-18 Mei 2014. 
Bobby DePorter \& Mike Hernacki. Quantum Learning Membiasakan Belajar Nyaman Dan Menyenangkan. Bandung: Kaifa, 2001.

Nuha, Ulin. Metode Super Efektif Pembelajaran Bahasa Arab. Yogjakarta: Diva Press, 2012.

Riyanto, Yatim. Paradigma Baru Pembelajaran. Jakarta: Kencana 2009.

Rosyidi, Abdul. Media Pembelajaran Bahasa Arab. Malang: UIN-Malang Press, 2009.

Trianto, Wahab. Mendesain Model Pembelajaran Inovatif-Progrsif. Jakarta: Kencana Premada Media Group, 2010.

\section{Sumber Internet:}

Ibnu Thaha. https://nahwusharaf.wordpress.com/2010/06/24/definisi$\underline{\text { sharaf/(23-12-2015) }}$

http://kbbi.web.id/ajar, Kamus Besar Bahasa Indonesia (KBBI) Kamus versi online/daring (dalam jaringan), 22-12-2015

http://unissula.ac.id/tamyis-metode-terjemah-quran-praktis/23-12-2015 